\title{
Effects of aqueous soybean, mistletoe and red clover extracts on activities of adenosine deaminase and xanthine oxidase enzymes
}

\author{
Namuslu $\mathrm{M}^{1}$, Kocaoglu $\mathrm{H}^{3}$, Celik $\mathrm{HT}^{1}$, Avci A ${ }^{2}$, Devrim E², Genc $\mathrm{Y}^{4}$, Gocmen $\mathrm{E}^{5}$, \\ Erguder $\mathrm{IB}^{2}$, Durak $\mathrm{I}^{2}$
}

Turgut Ozal University Faculty of Medicine, Department of Biochemistry, Ankara,Turkey. mnamuslu@yahoo.com

\begin{abstract}
Soybean (Glycine max), mistletoe (Viscum album) and red clover (Trifolium pratence) have been argued to have anti-cancer effects. In the present study it was aimed to investigate possible effects of these plant extracts on the activities of DNA turn-over enzymes, namely adenosine deaminase (ADA) and xanthine oxidase (XO) in cancerous and non-cancerous gastric and colon tissues. For this aim, 6 cancerous and 6 noncancerous adjacent human gastric tissues, and 7 cancerous and 7 non-cancerous adjacent colon tissues were obtained by surgical operations. Our results suggest that aqueous soybean, mistletoe and red clover extracts may exhibit anti-tumoral activity by depleting hypoxanthine concentration in the cancer cells through XO activation, which may lead to lowered salvage pathway activity necessary for the cancer cells to proliferate in the cancerous colon tissue. Some foods like soybean, mistletoe and red clover may provide nutritional support to medical cancer therapy through inhibiting and/or activating key enzymes in cancer metabolism (Tab. 4, Ref. 33). Text in PDF www.elis.sk.

Key words: gastric cancer, colon cancer, soybean, mistletoe, red clover, adenosine deaminase, xanthine oxidase.
\end{abstract}

Colorectal cancer is the fourth most common cancer in men and third most common cancer in women worldwide (1). Environmental factors including dietary habits are important in the development of colorectal and gastric cancers (2). Many studies have been performed on this subject by various clinical centers. There is still no convincing therapeutic method in the colorectal and gastric cancers that is good enough for such a complex disease. Combination of surgery, chemotherapy and radiotherapy is the choice of therapy in these cancers, but side effects affect the performance of these methods.

Many epidemiological studies have revealed that there are positive correlations between colon cancer and ingestion of animal fat and inverse correlations between colon cancer and diets rich in vegetables (3-5). Nagata et al. have observed that there are inverse correlation between soy product intake and gastric cancer mortality rate in men, and inverse correlation between soy product intake and colorectal cancer in men and women. Soybean consists of several biologically active components including proteins, isofla-

${ }^{1}$ Turgut Ozal University Faculty of Medicine, Department of Biochemistry, Ankara,Turkey, ${ }^{2}$ Ankara University Faculty of Medicine, Department of Biochemistry, Ankara,Turkey, ${ }^{3}$ Ankara University Faculty of Medicine, Department of Surgical Oncology, Ankara,Turkey, ${ }^{4}$ Ankara University Faculty of Medicine, Department of Biostatistics , Ankara,Turkey, and ${ }^{5}$ Ankara Numune Teaching and Research Hospital, Clinics of General Surgery, Ankara,Turkey

Address for correspondence: M. Namuslu, MD, Turgut Ozal Universitesi Tip Fakultesi, Biyokimya Anabilim Dali (Dekanlik Binası), 06510 Emek, Ankara,Turkey.

Phone: +903122035815, Fax: +903122213670 vones, saponins, fiber, oil and fatty acids. Saponins and isoflavones have protective effects on colorectal cancers. Soybean contains high quantities of the isoflavones, namely genistein and daidzein. Genistein is capable of inhibiting cancer cell growth by blocking tyrosine protein kinases and DNA topoisomerases $(6,7)$. Genistein has been shown to be anti-proliferative, to induce apoptosis and to inhibit angiogenesis, all of which are potential anti-cancer mechanisms (7). They have found that these correlations depend on the intake of soybean and isoflavones (8). They proposed that it is unknown yet whether soybean paste is protective or a risk factor for gastric cancer. Messina et al. suggested that risk for gastric cancer seemed to increase with the intake of fermented soybean foods and to decrease with the intake of non-fermented soybean foods (3). Mistletoe has beneficial properties such as anticancer (9, 10), antiviral (11), apoptosis-inducing (12) and immunomodulatory effects $(13,14)$. Mistletoe includes lectins which have cytotoxic effects on tumor cells and induction of apoptosis (15). Red clover is also a rich source of isoflavones. Genistein and daidzein are predominant isoflavones found in red clover (16).

ADA converts deoxyadenosine to deoxyinosine and ammonia and also converts adenosine to inosine and ammonia via hydrolytic deamination (17). XO, in the purine metabolism, catalyzes oxidation of xanthine and hypoxanthine, and it can produce superoxide radicals (18).

In this study it was aimed to investigate possible effects of soybean, mistletoe and red clover extracts on the activities of two DNA turn-over enzymes, namely adenosine deaminase (ADA) and xanthine oxidase $(\mathrm{XO})$ in human colon and gastric cancer tissues 


\section{Materials and methods}

Patients

Six cancerous and 6 non-cancerous adjacent human gastric tissues and, 7 cancerous and 7 non-cancerous adjacent colon tissues were obtained from cancer patients by surgical operations. The work was approved by the Ethics Committee of Ankara Numune Teaching and Research Hospital.

Treatment of tissues

The tissues were treated with aqueous extracts of 3 different herbs (Soybean, mistletoe and red clover) in vitro at 3 different final concentrations $(0.05 \%, 0.5 \%$ and $1.25 \%)$ for 1 hour. Activity assays were performed in the same samples without the extracts as well. Protein level of the tissues was studied by the Lowry method (19), after adjusting to equal concentrations.

Quantification of adenosine deaminase and xanthine oxidase activity

After and before incubation period, XO and ADA enzyme activities were measured by the spectrophotomery. Xanthine oxidase activity was determined by measuring the optical denstiy of uric acid, which is formed from xanthine (catalog number of xanthine X-0626, Sigma ) by xanthine oxidase, at $293 \mathrm{~nm}$ as described
(20). Adenosine deaminase activity was studied by the method of Guisti (21). ADA converts adenosine (catalog number of adenosine A-9251, Sigma) into inosine and ammonia. The resulting ammonia reacts with phenol and sodium hypochloride to create indophenol with blue color. The optical density of indophenol is measured at $628 \mathrm{~nm}$ by using spectrophotometry (Unicom He $\lambda$ ios- $\alpha$ UV-vis spectrophotometer). Enzyme activities were expressed as $\mu \mathrm{IU} / \mathrm{mg}$ protein and $\mathrm{mIU} / \mathrm{mg}$-protein for $\mathrm{XO}$ and ADA, respectively. IU is the amount of an enzyme that will catalyze the transformation of $10^{-6} \mathrm{~mol}(\mu \mathrm{mol})$ of substrate per minute. $\mathrm{mIU}$ is the amount of an enzyme that will catalyze the transformation of $10^{-9} \mathrm{~mol}(\mathrm{nmol})$ of substrate per minute.

\section{Statistical analysis}

The Friedman and Wilcoxon Signed Ranks tests were used for statistical evaluation of the results. Values of $p$ lower than 0.05 were considered as significant.

\section{Results}

The results are presented in the Tables $1-4$. In both cancerous and non-cancerous tissues, $\mathrm{XO}$ activities were found to elevate in correlation with increased extract concentrations in both cancer

Tab. 1. ADA activities in cancerous and noncancerous gastric tissues with and without extracts.

\begin{tabular}{|c|c|c|c|c|c|}
\hline \multirow[b]{2}{*}{ Extracts } & \multirow[b]{2}{*}{ Concentration } & \multicolumn{2}{|c|}{ Non-cancerous Tissue } & \multicolumn{2}{|c|}{ Cancerous Tissue } \\
\hline & & No Incubation & Incubation & No Incubation & Incubation \\
\hline \multirow[t]{4}{*}{ Red clover } & No extract & $72.87 \pm 65.90$ & $63.72 \pm 56.02$ & $40.60 \pm 33.64$ & $35.27 \pm 20.10$ \\
\hline & $0.1 \%$ & $70.36 \pm 63.69$ & $66.80 \pm 55.84$ & $34.50 \pm 31.11$ & $31.35 \pm 23.28$ \\
\hline & $1 \%$ & $72.82 \pm 64.81$ & $65.10 \pm 57.10$ & $34.96 \pm 34.61$ & $31.27 \pm 18.41$ \\
\hline & $2.5 \%$ & $73.01 \pm 69.53$ & $67.20 \pm 60.45$ & $35.23 \pm 30.11$ & $36.30 \pm 29.45$ \\
\hline \multirow[t]{4}{*}{ Mistletoe } & & $72.87 \pm 65.90$ & $63.72 \pm 56.02$ & $40.60 \pm 33.64$ & $35.27 \pm 20.10$ \\
\hline & $0.1 \%$ & $75.44 \pm 70.51$ & $64.23 \pm 58.49$ & $39.90 \pm 38.06$ & $32.87 \pm 19.80$ \\
\hline & $1 \%$ & $70.92 \pm 65.88$ & $67.29 \pm 60.63$ & $40.23 \pm 28.38$ & $40.62 \pm 22.95$ \\
\hline & $2.5 \%$ & $73.50 \pm 68.64$ & $64.17 \pm 56.00$ & $42.29 \pm 31.91$ & $37.12 \pm 15.97$ \\
\hline \multirow[t]{4}{*}{ Soy bean } & & $72.87 \pm 65.90$ & $63.72 \pm 56.02$ & $40.46 \pm 33.64$ & $35.27 \pm 20.10$ \\
\hline & $0.1 \%$ & $68.66 \pm 63.38$ & $63.42 \pm 57.46$ & $38.33 \pm 27.45$ & $35.20 \pm 22.78$ \\
\hline & $1 \%$ & $72.44 \pm 68.06$ & $72.70 \pm 60.20$ & $37.39 \pm 24.99$ & $28.76 \pm 26.51^{1}$ \\
\hline & $2.5 \%$ & $68.00 \pm 61.11$ & $69.24 \pm 58.55^{\mathrm{e}}$ & $35.14 \pm 28.16$ & $34.35 \pm 24.80$ \\
\hline
\end{tabular}

${ }^{\mathrm{e}} 0.1 \%$ vs. $\% 2.5,{ }^{1}$ incubated and non-cancerous tissue vs. incubated and cancerous tissue; $\mathrm{p}<0.05$.

Tab. 2. XO activities in cancerous and noncancerous gastric tissues with 3 different extracts and no exracts.

\begin{tabular}{|c|c|c|c|c|c|}
\hline \multirow[b]{2}{*}{ Extracts } & \multirow[b]{2}{*}{ Concentration } & \multicolumn{2}{|c|}{ Non-cancerous Tissue } & \multicolumn{2}{|c|}{ Cancerous Tissue } \\
\hline & & No Incubation & Incubation & No Incubation & Incubation \\
\hline \multirow{4}{*}{ Red clover } & No extract & $84.73 \pm 50.36$ & $76.79 \pm 57.47$ & $58.28 \pm 30.53$ & $43.16 \pm 23.35$ \\
\hline & $0.1 \%$ & $73.77 \pm 49.19$ & $79.90 \pm 37.21$ & $61.94 \pm 27.69$ & $50.95 \pm 24.852$ \\
\hline & $1 \%$ & $74.06 \pm 33.45$ & $71.74 \pm 24.06$ & $68.99 \pm 29.07$ & $69.99 \pm 27.43^{\mathrm{b}, \mathrm{d}}$ \\
\hline & $2.5 \%$ & $97.59 \pm 33.44$ & $106.76 \pm 39.60$ & $86.91 \pm 37.12^{\mathrm{c}, \mathrm{e}, \mathrm{f}}$ & $76.58 \pm 28.31^{\mathrm{c}, \mathrm{e}, \mathrm{f}}$ \\
\hline \multirow[t]{4}{*}{ Mistletoe } & & $84.73 \pm 50.36$ & $76.79 \pm 57.47$ & $58.28 \pm 30.53$ & $43.16 \pm 23.35$ \\
\hline & $0.1 \%$ & $71.65 \pm 43.67$ & $84.68 \pm 37.86$ & $57.89 \pm 25.49$ & $70.18 \pm 49.97$ \\
\hline & $1 \%$ & $90.68 \pm 45.83$ & $80.39 \pm 34.15$ & $78.16 \pm 39.77^{1}$ & $65.68 \pm 40.36$ \\
\hline & $2.5 \%$ & $84.64 \pm 32.46$ & $80.36 \pm 39.73$ & $85.16 \pm 26.8^{\mathrm{c}, \mathrm{e}}$ & $64.63 \pm 38.60$ \\
\hline \multirow[t]{4}{*}{ Soy bean } & & $84.7 \pm 350.36$ & $76.79 \pm 57.47$ & $58.28 \pm 30.53$ & $43.16 \pm 25.35$ \\
\hline & $0.1 \%$ & $66.65 \pm 46.15$ & $81.50 \pm 48.69$ & $66.90 \pm 23.17$ & $54.42 \pm 25.04$ \\
\hline & $1 \%$ & $59.55 \pm 35.46$ & $60.66 \pm 31.73$ & $60.26 \pm 27.07$ & $52.56 \pm 21.33$ \\
\hline & $2.5 \%$ & $54.55 \pm 26.20$ & $52.50 \pm 36.30$ & $61.57 \pm 23.28$ & $57.37 \pm 38.40$ \\
\hline
\end{tabular}

${ }^{\mathrm{b}} 1 \%$ vs. null, ${ }^{\mathrm{c}} 2.5 \%$ vs. null, ${ }^{\mathrm{d}} 0.1 \%$ vs. $1 \%,{ }^{\mathrm{e}} 0.1 \%$ vs. $2.5 \%,{ }^{\mathrm{f}} 1 \%$ vs. $2.5 \%,{ }^{1}$ no-incubated and non-cancerous tissue vs. no- incubated and cancerous tissue, ${ }^{2}$ incubated and non-cancerous tissue vs. incubated and cancerous tissue; $\mathrm{p}<0.05$. 
Tab. 3. ADA activities in cancerous and noncancerous colon tissues with 3 different extracts and no exracts.

\begin{tabular}{|c|c|c|c|c|c|}
\hline \multirow[b]{2}{*}{ Extracts } & \multirow[b]{2}{*}{ Concentration } & \multicolumn{2}{|c|}{ Non-cancerous Tissue } & \multicolumn{2}{|c|}{ Cancerous Tissue } \\
\hline & & No Incubation & Incubation & No Incubation & Incubation \\
\hline \multirow[t]{4}{*}{ Red clover } & No extract & $16.51 \pm 16.31$ & $17.38 \pm 16.97$ & $21.32 \pm 9.47$ & $19.58 \pm 8.21$ \\
\hline & 0.1 & $15.86 \pm 16.06$ & $20.21 \pm 18.29$ & $20.40 \pm 8.15$ & $21.40 \pm 6.06$ \\
\hline & 1 & $17.23 \pm 17.56$ & $23.30 \pm 23.14$ & $21.02 \pm 8.02$ & $22.30 \pm 5.65$ \\
\hline & 2.5 & $18.17 \pm 19.19$ & $17.84 \pm 19.86$ & $50.21 \pm 77.55$ & $21.05 \pm 6.66$ \\
\hline \multirow[t]{4}{*}{ Mistletoe } & & $16.51 \pm 16.31$ & $17.38 \pm 16.97$ & $21.32 \pm 9.47$ & $19.58 \pm 8.21$ \\
\hline & 0.1 & $10.07 \pm 5.20$ & $19.43 \pm 20.26$ & $17.33 \pm 10.58^{2}$ & $21.16 \pm 8.16$ \\
\hline & 1 & $13.28 \pm 7.15$ & $15.47 \pm 10.05$ & $20.82 \pm 8.16^{2}$ & $18.61 \pm 7.02^{3}$ \\
\hline & 2.5 & $18.66 \pm 22.64$ & $15.53 \pm 10.05$ & $21.12 \pm 9.27$ & $21.56 \pm 7.68$ \\
\hline \multirow[t]{4}{*}{ Soy bean } & & $16.51 \pm 16.31$ & $17.38 \pm 16.97$ & $21.32 \pm 9.47$ & $19.58 \pm 8.21$ \\
\hline & 0.1 & $16.95 \pm 16.02$ & $24.68 \pm 19.51^{\mathrm{a}, 1}$ & $22.43 \pm 7.6$ & $20.27 \pm 6.85^{3}$ \\
\hline & 1 & $17.66 \pm 14.44$ & $14.99 \pm 19.20^{\mathrm{b}}$ & $21.02 \pm 6.55$ & $23.34 \pm 10.88$ \\
\hline & 2.5 & $16.92 \pm 17.46$ & $16.92 \pm 17.46^{\mathrm{c}}$ & $23.48 \pm 7.49$ & $20.59 \pm 6.80$ \\
\hline
\end{tabular}

${ }^{\mathrm{a}} 0.1 \%$ vs. null, ${ }^{\mathrm{b}} 0.1 \%$ vs. $1 \%,{ }^{\mathrm{c}} 0.1 \%$ vs. $2.5 \%,{ }^{1}$ no-incubated and non-cancerous tissue vs. Incubated and non-cancerous tissue, ${ }^{2}$ no-incubated and non-cancerous tissue vs. no-incubated and cancerous tissue, ${ }^{3}$ no-incubated and cancerous tissue vs. incubated and cancerous tissue; $\mathrm{p}<0.05$.

Tab. 4. XO activities in cancerous and noncancerous colon tissues with 3 different extracts and no exracts.

\begin{tabular}{|c|c|c|c|c|c|}
\hline \multirow[b]{2}{*}{ Extracts } & \multirow[b]{2}{*}{ Concentration } & \multicolumn{2}{|c|}{ Non-cancerous Tissue } & \multicolumn{2}{|c|}{ Cancerous Tissue } \\
\hline & & No Incubation & Incubation & No Incubation & Incubation \\
\hline \multirow[t]{4}{*}{ Red clover } & No extract & $37.56 \pm 11.08$ & $38.62 \pm 3.77$ & $45.69 \pm 24.06$ & $41.16 \pm 24.02$ \\
\hline & $0.1 \%$ & $49.95 \pm 14.74^{\mathrm{a}}$ & $45.67 \pm 14.40$ & $67.97 \pm 62.10$ & $66.50 \pm 21.99^{a, 2}$ \\
\hline & $1 \%$ & $39.81 \pm 17.67$ & $44.98 \pm 13.92$ & $58.69 \pm 22.98^{\mathrm{b}, 1}$ & $62.74 \pm 24.97^{b}$ \\
\hline & $2.5 \%$ & $65.46 \pm 39.80$ & $67.76 \pm 23.68^{\mathrm{c}, \mathrm{e}, \mathrm{f}}$ & $68.86 \pm 21.34^{\mathrm{c}, \mathrm{f}}$ & $74.77 \pm 22.40^{\mathrm{c}, \mathrm{f}}$ \\
\hline \multirow[t]{4}{*}{ Mistletoe } & & $37.56 \pm 11.08$ & $38.62 \pm 3.77$ & $45.69 \pm 24.06$ & $41.16 \pm 24.02$ \\
\hline & $0.1 \%$ & $37.79 \pm 8.64$ & $33.91 \pm 11.93$ & $45.38 \pm 23.04^{1}$ & $55.17 \pm 26.06$ \\
\hline & $1 \%$ & $29.64 \pm 14.16^{b}$ & $30.74 \pm 7.49$ & $43.11 \pm 19.44^{1}$ & $51.35 \pm 22.19$ \\
\hline & $2.5 \%$ & $22.82 \pm 12.24^{\mathrm{c}, \mathrm{d}, \mathrm{e}, \mathrm{f}}$ & $16.41 \pm 8.57$ & $48.29 \pm 23.47^{1}$ & $47.15 \pm 11.71$ \\
\hline \multirow[t]{4}{*}{ Soy bean } & & $37.56 \pm 11.08$ & $38.62 \pm 3.77$ & $45.69 \pm 24.06$ & $41.16 \pm 24.02$ \\
\hline & $0.1 \%$ & $40.28 \pm 12.46$ & $35.10 \pm 10.09$ & $48.27 \pm 24.99$ & $46.01 \pm 15.59$ \\
\hline & $1 \%$ & $36.08 \pm 19.00$ & $44.68 \pm 15.00$ & $61.24 \pm 10.90^{1}$ & $52.82 \pm 9.00$ \\
\hline & $2.5 \%$ & $49.33 \pm 17.10$ & $55.37 \pm 27.81$ & $70.35 \pm 12.04^{1}$ & $69.26 \pm 14.68$ \\
\hline
\end{tabular}

${ }^{\mathrm{a}} 0.1 \%$ vs. null, ${ }^{\mathrm{b}} 1 \%$ vs. null, ${ }^{\mathrm{c}} 2.5 \%$ vs. null, ${ }^{\mathrm{d}} 0.1 \%$ vs. $1 \%,{ }^{\mathrm{e}} 0.1 \%$ vs. $2.5 \%,{ }^{\mathrm{f}} 1 \%$ vs. $2.5 \%,{ }^{1}$ no-incubated and non-cancerous tissue vs. no- incubated and cancerous tissue, 2 incubated and non-cancerous tissue vs. incubated and cancerous tissue; $\mathrm{p}<0.05$.

types. However, no change was found between ADA activities in the tissues.

It was found that soybean extract increased XO activity in cancerous colon tissue without preincubation. However, it inhibited the activity of $\mathrm{XO}$ in non-cancerous gastric tissue with and without preincubation.

It was observed that aqueous mistletoe extract significantly inhibited XO activity in non-cancerous colon tissue. However, it caused increases in the activity of $\mathrm{XO}$ in cancerous gastric tissue. Additionally, red clover caused significant increases in the $\mathrm{XO}$ activities of both cancerous tissues.

\section{Discussion}

Red clover has long been used to treat some cancer types among people. The use of red clover as an anticancer agent can be traced back to the 1940s when herbalists suggested the use of herbs as an alternative choice to surgery and radiation therapy $(22,23)$. Red clover contains high amounts of isoflavone compounds such as genistein, daidzein, formononetin and biochanin A (24). Several researchers have shown that these isoflavones may help prevent cancer. In a study, it has been demonstrated that isoflavone derivatives inhibit the cell growth of gastric can- cer lines in vitro and supposed that this might occur through activation of a signal transduction pathway for apoptosis. In another study, biochanin A, one of the isoflavones in red clover has been found to inhibit carcinogen activation in cells in culture medium (25). Biochanin A and formononetin are potent aryl hydrocarbon receptor (AhR) agonist, activation of which affects cell cycle and drives cells to apoptosis in vitro. Daidzein is another isoflavone in red clover. It is metabolized to equol in mammals which is associated with reduced incidence of breast cancer. In another study, the researchers found that, consumption of red clover before prostatectomy increased apoptosis in malignant tissue (26). However, the precise mechanism of action and responsible constituents for the proposed benefits of red clover in the cancer process are not clearly known yet.

Mistletoe has been used for the treatment of many diseases like solid cancers. Extracts from viscum album were used as complementary cancer treatments. It was found to reduce side effects during chemotherapy and adjuvant therapy (27). Mistletoe extracts also could reduce harmful and mutagenic effects of the oxygen free radicals generated during radiotherapy and chemotherapy $(28,29)$. Lectins are among the active constitutes of mistletoe extracts. Lectins caused strong cytotoxic effects on tumor cells by apoptosis. Viscum album coloratum agglutinin (VCA) is 
367-371

a lectin and isolated from Korean mistletoe. VCA drives cells to apoptosis by inhibiting telomerase activity. Khil et al. found that VCA selectively killed colon cancer cells but not normal human cells in vitro and in vivo. They found that VCA induced apoptosis in colon cancer cells due to activation of caspases and inhibition of anti-apoptotic proteins such as tumor necrosis factor (15). However, the precise mechanism of action and responsible constituents are also not known for the proposed benefits of Mistletoe in the cancer process.

Soybean contains several active components that may contribute individually or synergistically to the health benefits of this plant. It has been used for gastrointestinal cancers, especially for gastric and colon cancers $(30,31)$. Isoflavones, saponins, fiber, oils and fatty acids are the components of soybean that have been hypothesized to provide health benefits. Although several biological activities of this plant have been reported in many studies, Hong-Mei Nan suggested that no study was performed to examine soybean effects on DNA turn-over enzymes in vitro. Hong-Mei Nan et al. observed that soybean pastes were risk factors of gastric cancer (32).

Salted, smoked, pickled, and preserved foods rich in salt, nitrite, and preformed N-nitroso compounds have been reported to be associated with an increased risk of gastric cancer. In contrast, high intake of fresh fruit, raw vegetables, and antioxidants significantly reduced the risk of gastric cancer (33). Soybean was established to have protective role against gastric cancer in a study (9).

In the present study, we have found that soybean extract increases XO activity in cancerous colon tissue without preincubation. However, it inhibits the activity of XO in non-cancerous gastric tissue with and without preincubation. Additionally, it has been observed that aqueous mistletoe extract significantly inhibits XO activity in non-cancerous colon tissue. However, it has caused increases in the activity of $\mathrm{XO}$ in cancerous gastric tissue. Red clover causes significant increases in the XO activities of both cancerous tissues, namely gastric and colon tissues. Our results suggest that aqueous extracts of soybean, mistletoe and red clover may exhibit anti-tumoral activity by depleting hypoxanthine concentration through XO activation, which may lead to lowered salvage pathway activity necessary for the cancer cells to proliferate in the cancerous colon and gastric tissues. Hypoxanthine has been converted to inosine mono phosphate (IMP) by Hypoxanthine-Guanine Phosphoribosyl Transferase enzyme in this salvage pathway. As known, IMP is used in DNA senthesis For this reason, ADA and XO enzym activities were investigated in the present study. The validity of ancient medicine is now being evaluated and tested critically in some tissue models. Preventive and therapeutic trials of some plants such as soybean, red clover, mistletoe, etc. are still in the early stage, although there are many lines of research suggesting the potential effects of these plants on cancer as emphasized above. The current knowledge does not recognize these plants as a true alternative drug. However, we think that it will certainly find a place in future for their role in the cancer prevention and treatment regimens.
In our conclusion $t$ soybean, mistletoe and red clover may provide nutritional support and can be combined for medical cancer treatment. Additionally, XO enzym activity may be used in assesment of anti-cancer treatment in the future. However, the subject needs future investigations.

\section{References}

1. Parkin DM, Bray F, Ferlay J, Pisani P. Global Cancer Statistics. CA Cancer J Clin 2005; 55 (2): 74-108.

2. Kim YS, Milner JA. Dietary modulation of colon cancer risk. J Nutr 2007; 137: 2576-2579.

3. Spector D, Anthony M, Alexander D, Arab L. Soy consumption, colorectal cancer. Nutr Cancer 2003; 47: 1-12.

4. Steinmetz KA, Kushi LH, Bostick RM, Folsam AR, Potter JD. Vegetable, fruit, cancer. Cancer Cause Control 1991; 2: 325-357.

5. Thun MJ, Calle EE, Namboodiri MM. Risk factors for fatal colon cancer in a large prospective study. JNCI 1992; 84: 1491-1500.

6. Massina MJ, Persky V, Setchell KD, Barnes S. Soy intake, cancer risk: a review of the in vitro, in vivo data. Nutr Cancer 1994; 2: 113-131.

7. Oh YJ, Sung MK. Soybean saponins inhibit cell proliferation by suppressing PKC activation, induce differentiation of HT-29 human colon adenocarsinoma cells. Nutr Cancer 2001; 39: 132-138.

8. Nagata C. Ecological study of the association between soy product intake, mortality from cancer, heart disease in Japan. Int Epidemiol Assoc 2000; 2: 832-836.

9. Kim HJ, Chang WK, Kim MK, Lee SS, Choi BY. Dietary Factors, gastric cancer: a case-control study in Korea. Int J Epidemiol 2002; 97 : 531-535.

10. Büssing A. Mistletoe: A story with, open end. Anti Cancer Drugs 1997; 8: $1-2$.

11. Karagöz A, Onay E, Arda N, Kuru A. Antiviral potency of mistletoe (Viscum Album ssp. Album) extracts against human Parainfluenza Virus Type 2 in Vero cells. Phytother Res 2003; 17: 560-562.

12. Khil LY, Kim W, Lyu S et al. Mechanism involved in Korean mistletoe lectin induced apopitosis of cancer cells. World J Gastroenterol 2007; 28: $2811-2818$.

13. Lee JY, Kim JY, Lee YG, Byeon SE. In vitro immunomodulatory effects of Korean mistletoe lectin on functional activation of monocytic, macrophage-like cells. Biol Pharm Bull 2007; 30: 2043-2051.

14. Jurin M, Zarkovic N, Borovic S, Kissel D. Viscum album L. preparation Isorel modifies the immune response in normal, in tumour-bearing mice. Anticancer Drugs 1997; 1: 27-31.

15. Khil LY, Kim W, Lyu S, Park WB, Yoon JW et al. Mechanisms involved in Korean mistletoe lectin-induced apoptosis of cances cells. World J Gastroenterol 2007; 13: 2811-2818.

16. Tsao R, Papadopoulos Y, Yang R, Young JC, McRae K. Isoflavone profiles of red clovers, their distrubition in different parts harvested at different growing stages: J Agric Food Chem 2006; 54: 5797-5805.

17. Cunha JG. Adenosine deaminase. A pluridisciplinary enzyme. Acta Med Port 1991; 4 (6): 315-323.

18. Durak I, Isik AC, Canbolat O, Kavutcu M. Adenosine deaminase, 5 ' nucleotidase, xanthine oxidase, superoxide dismutase, and catalase ac- 
tivities in cancerous, noncancerous human laryngeal tissues. Free Radic Biol Med 1993; 15 (6): 681-684.

19. Lowry O, Rosebrough N, Farr L, Randall R. Protein measurement with folin phenol reagent. J Biol Chem 1951; 182: 265-275.

20. Hashimoto S. A new spectrophotometric assay method of xanthine oxidase in crude tissue homogenate. Anal Biochem 1974; 425-435.

21. Guisti G. Enzyme activities in: Bergmeyer UH, ed. Methods of enzymatic analysis. Weinheim Bergest: Verlag Chemia 1974; 1087-1091.

22. Leung AY, Foster S. Encyclopaedia of Common Natural Ingredients Used in Food, Drugs, Cosmetics. New York: John Wiley \& Sons, 1996; 177-178.

23. Rosenthal MA, Taneja S, Bosland MC. Phytoestrogens, prostate cancer: possible preventive role. Med J. 1998; 4: 168-169.

24. Booth NL, Overk CR, Yao P, Tatura S, Deng Y et al. Farnsworth NR. Seasonal Variation of Red Clover (Trifolium Pratence L. Fabaceae) Isoflavones, Estrogenic Activity. J Agric Food Chem 2006; 54: 1277-1282.

25. Cassady JM, Zennie TM, Chae YH, Ferin MA, Portuondo NE. Use of a mammalian cell culture benzoapyrene metabolism assay for the detection of the potential anticarcinogens from natural products: Inhibition of metabolism by Biochanin A, an isoflavone from Trifolium Pratense. Linn. Cancer Res 1998; 48: 6257-6261.
26. Medjakovi CS, Junpbaver A. Red clover isoflavones biochanin A, formononetin are potent ligands of the human aryl hydrocarbon receptor. J Steroid Biochem Mol Biol 2008; 108: 171-177.

27. Bar-sela G, Gershony A, Haim N. Mistletoe ( Viscum album) preprations: an optinal drug for cancer patients. Harefuah 2006; 145: 42-46.

28. Jurin M, Zarkovic N, Hrzenjak M, Ilic Z. Antitumorous, immunomodulatory effects of Viscum album Preparation Isorel. Oncology 1993; 50: 393-398.

29. Hulsen H, Kron R, Mechelke F. Influence of Viscum album of preparation on the natural killer cell-mediated cytotoxicity of peripheral blood. Naturwiss 1989; 76: 530-535.

30. Badger TM, Ronis MJ, Simmen RC, Simmen FA. Soy protein 1solate, protection against cancer. J Am Coll Nutr 2005; 24: 146-149.

31. Messina M. Modern applications for an ancient bean: soybeans, the prevention, treatment of chronic disease. J Nutr 1995; 125: 567-569.

32. Nan HM, Park JW, SongYJ, Yun HY, Park JS. Kimchi, soybean pastes are risk factors of gastric cancer. World J Gastroenterol 2005; 11 (21): $3175-3181$.

33. Palli D. Epidemiology of gastric cancer: an evaluation of available evidence. J Gastroenterol 2000; 35: 84-89.

Received January 28, 2013. Accepted March 8, 2014. 